\title{
Microbiological Conditions of Frozen Shrimp in Different Food Market of Dhaka City
}

\author{
F. R. PInu ${ }^{1}$, Sabina Yeasmin ${ }^{2}$, Md. Latiful BARI ${ }^{3 *}$ and M. M. RAHMAN ${ }^{1}$ \\ ${ }^{1}$ Department of Microbiology, Stamford University Bangladesh, 51, Siddeswari Road, Dhaka 1217, Bangladesh \\ ${ }^{2}$ Department of Genetic Engineering and Biotechnology Dhaka University, Dhaka-1000, Bangladesh \\ ${ }^{3}$ Food Hygiene Laboratory, National Food Research Institute, 2-1-12, Kannondai, Tsukuba-shi, Ibaraki 305-8642, Japan
}

Received September 11, 2006; Accepted June 7, 2007

\begin{abstract}
This study was carried out to evaluate the microbiological condition of the frozen shrimps found in the local markets and departmental chain shops of Dhaka city. Pathogenic bacterial load were found greater in the samples of departmental shops rather than that of local markets. The highest Aerobic Plate Count (APC) found in the samples of departmental shops and local markets were $8.74 \log _{10} \mathrm{CFU} / \mathrm{g}$ (sample No. 14) and $8.30 \log _{10} \mathrm{CFU} / \mathrm{g}$ (sample No. 8), respectively. However, the lowest APC found in the samples of departmental shops and local markets were $5.73 \log _{10} \mathrm{CFU} / \mathrm{g}$ (sample No. 5) and $6.44 \log _{10} \mathrm{CFU} / \mathrm{g}$ (sample No. 12), respectively. Presence of Vibrio spp. was confirmed in 8 samples ( 5 from departmental shops and 3 from local markets). It was confirmed that 8 samples contained Shigella spp and 11 samples had Salmonella spp. Antibiotic sensitivity pattern of the indicator and pathogenic isolates was determined and nearly all of them were resistant to penicillin and bacitracin. Most of the isolates were sensitive against tetracycline, kanamycin and chloramphenicol. It was observed from the study that the samples collected from local markets and departmental shops were heavily contaminated and are of special concern for human consumption.
\end{abstract}

Keywords: Microbiology, Frozen Shrimp, Food Market

\section{Introduction}

Both marine and fresh water fish are natural resources in Bangladesh, which cater to the enormous need of protein and other nitrogenous constituents (14). The economic potential of the marine fisheries sector in Bangladesh is considered to be enormous in recognition of the country's 710 kilometers coastline and Exclusive Economic Zone, which spreads over an area of 164,000 square kilometers. According to Bangladesh Statistical Year Book, Bangladesh exported 26.56 million tons shrimp during last fiscal year 2003-2004 (5).

The major part of the shrimps exported from Bangladesh is destined for USA (31.8\%), Japan (18.3\%), Belgium $(16.2 \%)$ and U.K. (11\%). Shrimp culture in Bangladesh is predominantly carried out by non-local entrepreneurs on leased-in lands (4).

Microbiological condition of the shrimp is mainly depended on the condition of transport, handling and processing. Frozen shrimps are often contaminated after catching during the above-mentioned steps (17). The water used to wash shrimp may be contaminated heavily with spoilage organisms and pathogens that can grow on the shrimp. Proper handling of shrimp between harvesting and marketing to the consumer is a crucial element in assuring quality of the final product. Standards of sanitation, method of handling and the time/temperature of holding shrimp are all significant factors to assure quality

\footnotetext{
* To whom correspondence should be addressed.
}

E-mail: latiful@affrc.go.jp
(20). With a few exceptions, fish are considered free of pathogenic bacteria of public health significance when first caught. The presence of bacteria harmful to humans generally indicates poor sanitation in handling and processing, and the contamination is almost always of human or animal origin.

The objective of this study was to determine the microbiological status of frozen shrimps in departmental shops and local markets of Dhaka city. Specific objectives are: 1) presence of pathogen in frozen shrimp in the local markets, 2) presence of indicator organisms of fecal pollution (coliforms, Escherichia coli) 3) or other types of pathogens or indicator organisms 4) indicator organisms if any and their antibiotic sensitivities were also examined.

\section{Materials and Methods}

Collection of shrimp samples Shrimp samples were collected from different departmental shops and local retail shops at Dhaka city in between August 2005 to February 2006. Total twenty samples were collected and analyzed for the microbiological status of the shrimp sample. Among the 20 samples, 10 were collected from departmental chain shops and 10 were from local markets. The shrimp samples were transported to the laboratory in an insulated box with ice to maintain the temperature (4 to 6 ${ }^{\circ} \mathrm{C}$ ) and stored at $-18^{\circ} \mathrm{C}$ at the laboratory until use. Special sterile Ziploc bags were used for carrying/thawing all the samples to avoid further contamination. Samples were processed and used within 24 hours of collection.

Processing of the samples The samples were thawed 
at room temperature for $5-6 \mathrm{~h}$ to melt the ice and were taken to the safety cabinet to peel off the shell and removing the head. The edible part body was taken and made small pieces using sterile scissors. Twenty five (25) grams of shrimp sample was measured carefully and accurately by using a weighing machine and dissolved in $225 \mathrm{~mL}$ of physiological saline $(0.85 \% \mathrm{NaCl}$ solution) in a stomacher bag. Each sample was then stomached for 60 seconds separately. One milliliter $/ 0.1 \mathrm{~mL}$ of the stomachertreated samples was then pour or spread plated in the microbiological medium as describe below:

Microbiological analysis The microbiological analysis was performed as per the standard methods adopted from Online Bacteriological Analytical Manual, USFDA for detection, enumeration and identification of individual organisms (3).

Aerobic plate count (APC) After appropriate serial dilutions, the samples were pour-plated on nutrient agar (Becton Dickinson, France). The colonies were counted after $24 \mathrm{~h}$ of incubation at $35^{-} 37^{\circ} \mathrm{C}$.

Coliform count Dilutions made for APC were pourplated on MacConkey agar (Oxoid Ltd., Hampshire, England); Typical pink colonies were counted after $24 \mathrm{~h}$ of incubation at $35-37^{\circ} \mathrm{C}$.

Fecal coliform and E. coli Dilutions made for APC were pour-plated on MacConkey agar (Oxoid Ltd., Hampshire, England). Typical colonies were counted after $24 \mathrm{~h}$ of incubation at $35-37^{\circ} \mathrm{C}$. The suspected $E$. coli isolates were streaked on $\mathrm{mFC}$ agar plates and incubated at $44.5^{\circ} \mathrm{C}$ for $24 \mathrm{~h}$. Typical blue colonies were counted and was further confirmed by growing in eosin methylene blue (EMB) agar plates (Oxoid Ltd., Hampshire, England).

Staphylococci count Dilutions made for APC were spread-plated on mannitol salt agar (MSA) (Oxoid Ltd., Hampshire, England). Typical yellow colonies were counted after $48 \mathrm{~h}$ of incubation at $35^{\circ} \mathrm{C}$.

Salmonella The sample (25 g) was homogenized in selenite cysteine broth and incubated overnight at $37^{\circ} \mathrm{C}$. After the samples were enriched a loopful of growth from the broth was streaked on Salmonella-Shigella agar (SSA; Oxoid), typical black colonies from plates were isolated and identified by biochemical tests.

Shigella spp. The sample (25 g) was homogenized in $225 \mathrm{~mL}$ of sterile physiological saline. After appropriate serial dilutions, the samples were pour-plated on xylose lysine deoxycholate (XLD) agar (Oxoid Ltd., Hampshire, England). Typical pink and translucent colonies with or without rough edges were picked up after $48 \mathrm{~h}$ of incubation at $35-37^{\circ} \mathrm{C}$ and were confirmed by biochemical tests.

Vibrio spp. The sample (25 g) was homogenized in $225 \mathrm{~mL}$ of alkaline peptone water (APW) and incubated at $35^{\circ} \mathrm{C}$ for $24 \mathrm{~h}$. After appropriate serial dilutions, the homogenates were pour-plated on TCBS agar (Oxoid Ltd., Hampshire, England). The suspected Vibrio isolates were then grown in different $\mathrm{NaCl}$ concentration as 3, 5, 10 and $15 \%$ and were confirmed by biochemical tests.

Biochemical tests Biochemical tests were done according to the manual for general bacteriology of the American Society of Microbiology (2). Biochemical tests done were as follows: oxidase test, catalase test, carbohydrate fermentation/ utilization test, Kligler's iron agar (KIA) test, indole production test, methyl red (MR) test, Voges-Proscauer (VP) test, citrate utilization test, nitrate reduction test, motility indole urea (MIU) tests, and salt tolerance $(3 \%, 5 \%, 10 \%$ and $15 \% \mathrm{NaCl})$ test were performed to identify the bacteria of interest (7).

Determination of antibiotic susceptibility of the isolated pathogens from shrimp samples Susceptibility of E. coli, Salmonella, Shigella, Vibrio and Staphylococcus isolates to different antimicrobial agents was measured in vitro according to the Kirby-Bauer methods (5). Commercially available antimicrobial discs [ampicillin (AMP), amoxicillin (AML) bacitracin (B), chloramphenicol (C), ciprofloxacin (CIP), erytromycin $(E)$, gentamycin $(\mathrm{GN})$, penicillin $\mathrm{G}(\mathrm{PG})$, streptomycin (S), tetracycline (TE), penicillin (P) and kanamycin $(\mathrm{K})]$ were used for the test. The E. coli, Salmonella, Shigella, Vibrio and Staphylococcus isolates were used against the antibiotics.

\section{Results and Discussion}

Aerobic plate count (APC) of the frozen shrimp samples Estimation of bacterial numbers in shrimp is frequently used to retrospectively assess microbiological quality or to assess the presumptive safety of the product. The APC of all the samples were found high and cross the limit given by International Commission on Microbiological Specifications for Foods (ICMSF). The high microbial load could deteriorate the product quality within short time. The highest load was found in sample14 $\left(8.74 \log _{10}\right.$ $\mathrm{CFU} / \mathrm{g})$ and the lowest load was in sample $7\left(5.17 \log _{10}\right.$ $\mathrm{CFU} / \mathrm{g}$ ) (Table 1 and 2). This might be because of the contamination from the source of water, poor hygiene and sanitation condition of the processing premises (18). Usually in Bangladesh, in the ghers or other catching side shrimps are collected in boats or trawlers. The surfaces of these places are contaminated due to lack of proper washing and inadequate disinfections. Catching vessels also act as source of contamination of harmful microorganisms (17). As a result many microbes begin to multiply before freezing. But freezing only can limit the growth of microbes for a short period. When favorable condition comes back, most of the microbes can multiply within short time (16).

Coliform bacteria Total coliforms were present in all the samples in high number. According to ICMSF limits,

Table 1. Average population of aerobic mesophilic, coliform and fecal coliform counts in shrimp samples of local markets.

\begin{tabular}{|c|c|c|c|c|}
\hline Sample No & Source & \multicolumn{3}{|c|}{ Population $\log _{10}$ CFU/g: } \\
\cline { 3 - 5 } & & $\begin{array}{c}\text { Aerobic mesophilic } \\
\text { bacteria }\end{array}$ & $\begin{array}{c}\text { Total coliform } \\
\text { bacteria }\end{array}$ & $\begin{array}{c}\text { Fecal coliform } \\
\text { /E.coli }\end{array}$ \\
\hline 1 & Local & 7.41 & 5.81 & 1.0 \\
\hline 2 & Local & 7.47 & 5.92 & ND \\
\hline 8 & Local & 8.30 & 4.50 & 2.0 \\
\hline 9 & Local & 6.65 & 3.36 & 0.9 \\
\hline 12 & Local & 6.44 & 3.46 & 1.08 \\
\hline 13 & Local & 7.60 & 4.64 & 2.15 \\
\hline 16 & Local & 6.62 & 2.70 & ND \\
\hline 17 & Local & 7.68 & 3.72 & ND \\
\hline 18 & Local & 7.55 & 3.39 & 1.34 \\
\hline 19 & Local & 6.61 & 5.85 & $1.56 /+$ Ve \\
\hline Average population, $7.23 \log _{10}$ CFU/g, Standard Deviation, $0.58, \mathrm{n}=10$, ND, not detected \\
\hline \multicolumn{5}{|r|}{} \\
\hline \multicolumn{5}{|l}{}
\end{tabular}


Table 2. Average population of aerobic mesophilic, coliform and fecal coliform counts in shrimp samples of departmental shop.

\begin{tabular}{|c|c|c|c|c|}
\hline \multirow{2}{*}{ Sample No } & \multirow{2}{*}{ Source } & \multicolumn{3}{|c|}{ Population $\log _{10}$ CFU/g: } \\
\cline { 3 - 5 } & & $\begin{array}{c}\text { Aerobic mesophilic } \\
\text { bacteria }\end{array}$ & $\begin{array}{c}\text { Total coliform } \\
\text { bacteria }\end{array}$ & $\begin{array}{c}\text { Fecal coliform } \\
\text { /E.coli }\end{array}$ \\
\hline 3 & Dept. & 6.08 & 4.70 & ND \\
\hline 4 & Dept. & 6.90 & 4.76 & 1.69 \\
\hline 5 & Dept. & 5.73 & 5.73 & 0.60 \\
\hline 6 & Dept. & 7.95 & 4.89 & ND \\
\hline 7 & Dept. & 5.17 & 5.71 & $2.34 /+$ Ve \\
\hline 10 & Dept. & 7.08 & 3.41 & ND \\
\hline 11 & Dept. & 8.53 & 3.70 & ND \\
\hline 14 & Dept. & 8.74 & 3.15 & 2.47 \\
\hline 15 & Dept. & 5.50 & 2.70 & ND \\
\hline 20 & Dept. & 5.77 & 4.25 & 1.30 \\
\hline Average population, 6.71 $\log _{10}$ CFU/g, Standard Deviation, $1.18, \mathrm{n}=10$, ND, not detected \\
\hline \multicolumn{5}{|l|}{}
\end{tabular}

$2.0 \log _{10} \mathrm{CFU} / \mathrm{g}$ can be present in the seafood. All the sample exceeded this limit. The highest load was $5.92 \log _{10}$ $\mathrm{CFU} / \mathrm{g}$ in sample 2 and the lowest load was $2.70 \log _{10} \mathrm{CFU} /$ $\mathrm{g}$ of sample 14 and 15 (Table 1 and 2). The presence of total coliform suggests the unhygienic condition or not properly handled of the shrimp samples including holding temperature. Moreover, the contamination may also come from wash water or water use for iceing (10). Therefore, it is necessary to use good quality water to avoid contamination.

Fecal coliform and E. coli Fecal coliform like E. coli are the group of the total coliforms that are considered to be present specifically in the gut and feces of warmblooded animals. Because the origins of fecal coliforms are more specific than the origins of the total coliform group of bacteria, fecal coliforms are considered a more accurate indication of animal or human waste than the total coliforms (8). About $80 \%$ of the shrimp samples was found contaminated with the fecal coliform; $20 \%$ of them was found contaminated with $E$. coli (Table 1 and 2). This result indicates that the water or processing vessels are somehow contaminated fecally. Despite the fact that they cannot be linked directly to contamination by human sewage, since this bacteria found in high concentration within sewage/septic systems. However, the presence of E. coli is not permitted in the shrimp samples in Japan, USA and other European countries. (21)

Load of pathogenic bacteria The presence of total and fecal coliform suggested that other harmful and pathogenic microorganisms such as Salmonella, Shigella, Vibrio spp. and Staphylococcus aureus are present in the samples. For that reason, further identification procedure was carried out to find out the pathogens.

Salmonella Salmonella are usually transmitted to humans by eating foods contaminated with animal feces. Contaminated foods are often of animal origin, such as beef, poultry, milk, or eggs, but all foods, including vegetables may become contaminated. Many raw foods of animal origin are frequently contaminated, but fortunately, though cooking kills Salmonella. The unwashed hands of an infected food handler, who forgot to wash his or her hands with soap after using the bathroom, may also contaminate food (9). Salmonella was identified in 11 samples out of 20 (Table 3 ).

A recent review by Reilly et al. (19), presented the evidence that farmed tropical shrimps frequently contain
Table 3. Presence of Salmonella, Shigella, Vibrio spp. and Staphylococcus spp. in different shrimp samples.

\begin{tabular}{|c|c|c|c|c|}
\hline \multirow{2}{*}{$\begin{array}{c}\text { Sample } \\
\text { No }\end{array}$} & \multicolumn{5}{|c|}{ Population $\log _{10}$ CFU/g: } \\
\cline { 2 - 5 } & Salmonella spp. & Shigella spp. & Vibrio spp. & Staphylococcus spp. \\
\hline 1 & 2.34 & 2.04 & 1.30 & 5.63 \\
\hline 2 & ND $^{\mathrm{a}}$ & 1.47 & 1.47 & 4.50 \\
\hline 3 & 1.30 & ND & 1.0 & 3.64 \\
\hline 4 & 2.30 & 2.11 & 0.90 & 5.43 \\
\hline 5 & ND & ND & ND & 3.77 \\
\hline 6 & ND & 1.41 & ND & 2.85 \\
\hline 7 & 2.0 & ND & 1.44 & 4.51 \\
\hline 8 & ND & ND & ND & 4.51 \\
\hline 9 & 1.50 & 1.34 & ND & 2.96 \\
\hline 10 & ND & ND & 1.08 & 3.56 \\
\hline 11 & ND & ND & ND & 4.64 \\
\hline 12 & 1.68 & ND & ND & 2.34 \\
\hline 13 & 1.41 & ND & ND & 3.73 \\
\hline 14 & 1.14 & 1.36 & ND & 4.47 \\
\hline 15 & ND & ND & 1.38 & 3.04 \\
\hline 16 & ND & ND & ND & 3.41 \\
\hline 17 & 1.11 & 1.56 & ND & 3.57 \\
\hline 18 & ND & ND & ND & 4.69 \\
\hline 19 & 1.3 & 1.17 & 0.69 & 2.47 \\
\hline 20 & 1.0 & ND & ND & 4.79 \\
\hline
\end{tabular}

${ }^{\mathrm{a}} \mathrm{ND}$, not detected.

Salmonella. It has also been demonstrated that Salmonella in aquaculture shrimp products originates from the environment rather than from poor standards of hygiene, sanitation, and poultry manure as feed. Most shrimps are cooked prior to consumption. These products, therefore, pose minimal health risks to the consumers except for cross contamination in the kitchens (11).

Shigella spp. All Shigella spp. have been implicated in foodborne outbreaks, however, S. sonnei is clearly the leading cause of shigellosis from food. Shigella are present in the diarrheal stools of infected persons while they are sick and for a week or two afterwards (22). Shigella infections may be acquired from eating contaminated food. Infected food handlers who forget to wash their hands with soap after using the bathroom may contaminate food. In this study, 8 samples were found to be contaminated with Shigella spp (Table 3).

Vibrio spp. In case of Vibrio spp., eight samples were found to be containing this bacterial species. The highest load was found in sample $2\left(1.47 \log _{10} \mathrm{CFU} / \mathrm{g}\right)$ (Table 3$)$. It is very unusual to find Vibrio spp. in frozen samples because Vibrio normally cannot survive in the frozen samples and it requires moisture to remain alive (13). The reason of survival of Vibrio spp in frozen shrimp samples was probably the inadequate freezing condition and presence of moisture during freezing.

However, no Vibrio cholera and Vibrio parahaemolyticus were found in all the sample tested.

Staphylococcus spp. Seafood may be contaminated with Staphylococcus via infected food handlers or from the environment. More often the contamination is from an infected individual with an infection on hands or with a cold or sore throat. Staphylococci are poor competitors and do not grow well in the presence of other microorganisnms (1). Thus, the presence of staphylococci in raw, naturally contaminated food is of little significance. In contrast, rapid growth and toxin production can take place in precooked seafood (shrimp) if recontaminated with $S$. aureus produces a large amounts of enterotoxin, when growing in the food. These toxins are generally 
Table 4. Antibiotic sensitivity of E. coli, Salmonella, Shigella and Staphylococcus isolates.

\begin{tabular}{|c|c|c|c|}
\hline Isolated strains & Resistant & Intermediate & Sensitive \\
\hline E. coli-1 & $\begin{array}{c}\text { P, AMP, E, B, } \\
\text { AML }\end{array}$ & PG & C, K, S, TE \\
\hline E. coli-2 & P, B, E, PG & AMP, TE & K, CN, S, AML \\
\hline E. coli-3 & E, PG, B, P & AMP & K, C, CN, S, TE \\
\hline E. coli-4 & P, B, E & C, CN, AML & K, S, TE, PG \\
\hline E. coli-5 & $\begin{array}{c}\text { E, PG, CN, TE, } \\
\text { S, P }\end{array}$ & AMP & K, S, B \\
\hline Salmonella-1 & P, B & AMP, AML & PG, TE, K, C, CN, S \\
\hline Salmonella-2 & P, PG, B & AMP & AMP, K, C, CN, AML, TE \\
\hline Shigella & $\begin{array}{c}\text { AML, PG, P, B, } \\
\text { TE, C }\end{array}$ & AMP, E & CN, K \\
\hline Staphylococcus-1 & $\begin{array}{c}\text { AMP, AML, P, } \\
\text { B, TE }\end{array}$ & Nil & C, S, PG, K, E \\
\hline Staphylococcus-2 & $\begin{array}{c}\text { AML, AMP, B } \\
\text { TE, K, E }\end{array}$ & S, K, PG, P \\
\hline
\end{tabular}

Abbreviations: Ampicillin (AMP), Amoxicillin (AML), Bacitracin (B), Chloramphenicol (C), Ciprofloxacin (CN), Erytromycin (E), Gentamycin (GN), Penicillin G (PG), Streptomycin $(\mathrm{S})$, Tetracycline $(\mathrm{TE})$, Penicillin $(\mathrm{P})$ and Kanamycin (K).

very resistant to proteolytic enzymes and heat. The heat applied in pastuerization and normal household cooking is not sufficient to destroy the toxin (18). There are considerable numbers of Staphyloccus spp. found in allmost all the sample tested (Table 3). However, there were no $S$. aureus in the samples tested.

Antibiotic sensitivity pattern of E. coli, Shigella, Salmonella and Staphylococcus isolates Ten isolates (five E. coli, two Salmonella, one Shigella and two Staphylococcus spp.) and twelve antibiotics (AMP, AML, B, C, CIP, E, GN, PG, S, TE, $\mathrm{P}$ and $\mathrm{K}$ ) were used for the sensitivity test. It was found that all isolates were resistant against PG (Table 4). Among the five isolates of $E$. coli, four were resistant to PG, B and E. Salmonella and Shigella isolates were also sensitive to PG and B. Both Staphylococcus isolates were resistant to AML, AMP, B and one isolate was found resistant to TE. The uncontrolled and irresponsible use of antibiotics and other chemotherapeutic agents are responsible for the occurrence of the antibiotic resistant trait among the pathogens and the majority of the drug resistant bacteria carry drug resistant ( $\mathrm{R}$ ) factor (15). It was interesting to observe some antibiotic sensitive strains in this study.

\section{Conclusion}

Our study demonstrated that the levels of bacteria in the frozen shrimp were found higher than the limit offered by ICMSF. The total aerobic bacteria, and coliform count was found higher which indicates the unhygienic condition of the processing area. There was considerable Vibrio spp. observed in all samples, which represents unhygienic condition of the production pond or feed. No Staphylococcus aureus was detected in the samples tested. However, the presence of pathogenic bacteria like E. coli, Shigella and Salmonella is of special concern. This result suggested that microbiological conditions of shrimps sold in local markets are of special concern. However, most prawns or shrimps are cooked prior to consumption, these products therefore, pose minimal health risks to the consumer except for cross contamination in kitchens (18).

\section{References}

1. Abigail, A. Salyers and Whitt, D.D. (1994). Bacterial Pathogenesis: A molecular approach, ASM press, Washington D.C. $1^{\text {st }}$ edition. p: 136.

2. American Society of Microbiology (1981). Manual for General Bacteriology Website: http://ourfood.com/General_bacteriology. html. Accessed on July 21, 2006.

3. Bacteriological Analytical Manual (BAM 2005), USFDA for detection, enumeration and identification of individual organisms. Accessed on July 21, 2006. http://www.foodinfonet. com/publication/fdaBAM.htm

4. Bangladesh Center for Advanced Studies (BCAS). (2002). The coastal shrimp sector in Bangladesh. Dhaka, Bangladesh: Annual report. p. 24, 63, 65.

5. Banik, R.C.K. and Humayun, N.M. (1999). Information on fish of Bangladesh. Official report, Department of Fisheries, Dhaka, Bangladesh.

6. Bauer, A.W., Kirby, W.M., Sheris, J.C. and Turck, M. (1996). Antibiotic susceptibility testing by a standardized single disc method. Am. J. of Clinc. Path., 45, 149-158.

7. Cappuccino James G. and Sherman, N. (1990). Microbiology: A Laboratory Manual. $4^{\text {th }}$ Edition. p. 137-183

8. Center for Disease Control and Prevention, FAQ. Escherichia coli. Website: http://www.cdc.gov/ncidod/dbmd/diseaseinfo/ escherichiacoli_g.htm

9. Center for Disease Control and Prevention, FAQ. Salomonellosis. Website: http://www.cdc.gov/ncidod/dbmd/diseaseinfo/ salmonellosis_g.htm

10. Claude E. Boyd (1990). Water quality in pond for aquaculture. Auburn University, Auburn, Alabama. P: 482.

11. Huss, H.H. (1993). Assurance of Seafood quality. FAO Fisheries Technical Paper, Rome. P: 94, 97, 169.

12. Liston, J. Fish and shellfish and their products. In: International Commission on Microbiological Specifications for FoodsICMSF (eds) Microbial ecology of foods vol. 2- Food commodities, Academic Press, New York, 1980, Vol. (2): 567-605.

13. James M. Jay. (1996). Modern Food Microbiology. $4^{\text {th }}$ edition. p: $583-585$.

14. Karim, Mahmudul. (2003). A gross oversimplification: Stop blaming shrimp. Dhaka, Bangladesh: Shrimp Seal of Quality Organization official paper, p: 1.

15. Keys, A., Aderson, J.T. and Grande, F. (1986). Metabolism. $6^{\text {th }}$ edition. p: 64.

16. Mauro Faber de Freitas Leitão, Daniel de Pinho Astacio Rios (2000). Microbiological and chemical changes in freshwater prawn stored under refrigeration. Braz. J. Microbiol, 31, 3-7.

17. Md. Abdul Wahab, Asbjorn Bergheim, and Bjorn Braaten (2003). Water quality and partial mass budget in extensive shrimp ponds in Bangladesh Science direct Internet (ed)., 218, 413-423.

18. Mohamed Hatha A.A, Maqbool, T.K. and Kumar, S. (2003). Microbial quality of shrimp products of export trade produced from aquacultured shrimp. Int. J. Food Microbiol., 82, 213-221.

19. Reilly, P.J.A., D.R. Twiddy and R.S. Fuchs (1992). Review of the occurrence of Salmonella in cultured tropical shrimp. FAO Fish. Circ. No. 851. FAO, Rome, Italy.

20. Robinson R.K (1985). Microbiology of Frozen foods. $1^{\text {st }}$ edition. p: 187, 195.

21. FAO Fisheries Department (1997). Review of the state of world aquaculture. FAO Fisheries Circular No. 886 FIRI/ C 886 (Rev.1). Website: http: //www.fao.org/fi/

22. World Health Organization (1995). Training Aspects of the Hazard Analysis Critical Control Point System. Report of a WHO Workshop on Training in HACCP with the participation of FAO, Geneva, 1-2 June 1995.WHO document WHO/ FNU/FOS/96.3. Website: http://www.who.int/foodsafety/ fs_management/en/haccp98.pdf 